\title{
Gross Anatomy of Urethra and Penis in Uncastrated and Castrated Buck of Black Bengal Goat
}

\author{
Anatomía Macroscópica de la Uretra y el Pene en Macho \\ Castrado y No Castrado de Cabra de Bengala Negra \\ Reajul Islam'; Syed Sayeem Uddin Ahmed²; Omar Faruk Miazi ${ }^{3}$; \\ A. S. M. Golam Kibria ${ }^{4}$; Abdullah Al Faruq ${ }^{4} \&$ Mohammad Mejbah Uddin ${ }^{4}$
}

\begin{abstract}
ISLAM, R.; AHMED, S. S. U.; FARUK, M. O.; KIBRIA, A. S. M. G.; FARUQ, A. A. \& UDDIN, M. M. Gross anatomy of male urethra and penis in uncastrated and castrated buck of Black Bengal goat. Int. J. Morphol., 39(1):138-142, 2021.

SUMMARY: Urethral process, sigmoid flexure, urethra at the pelvic arch and neck of urinary bladder in goats are very much prone to form obstructive urolithiasis. The present study was carried out to establish baseline work on the normal measurement of the urethral passage and different segments of penis of uncastrated and castrated Black Bengal (BB) goat which will be supportive for obstructive urolithiasis management. Different segment of penis along with urethra of 25 uncastrated and 25 castrated male Black Bengal goats were collected from different slaughter house of Chattogram City Corporation. The length and diameter of male urethra and different segment of penis in uncastrated buck were significantly higher $(\mathrm{p}<.001)$ than castrated buck. The length of the pelvic urethra was $5.88 \pm 0.111 \mathrm{~cm}$ and $4.58 \pm 0.15 \mathrm{~cm}$ in uncastrated and castrated buck respectively. The length of the neck of urinary bladder; root, body, sigmoid flexure, glans penis and urethral process of the penis in uncastrated and castrated buck were $0.688 \pm 0.156 \mathrm{~cm}$ and $0.38 \pm$ $0.048 \mathrm{~cm}, 5.02 \pm 0.09 \mathrm{~cm}$ and $4.24 \pm 0.10 \mathrm{~cm}, 23.48 \pm 0.37 \mathrm{~cm}$ and $22.74 \pm 0.43 \mathrm{~cm}, 9.2 \pm 0.107 \mathrm{~cm}$ and $8.18 \pm 0.29 \mathrm{~cm}, 1.92 \pm 0.032 \mathrm{~cm}$ and $1.44 \pm 0.10 \mathrm{~cm}, 2.32 \pm 0.029 \mathrm{~cm}$ and $1.78 \pm 0.07 \mathrm{~cm}$ respectively. The diameter of the neck of urinary bladder, root, body, sigmoid flexure, glans penis and urethral process of the penis in uncastrated and castrated buck were $1.94 \pm 0.041 \mathrm{~cm}$ and $1.44 \pm 0.05 \mathrm{~cm}, 3.7 \pm$ $0.049 \mathrm{~cm}$ and $3.3 \pm 0.144 \mathrm{~cm}, 2.63 \pm 0.066 \mathrm{~cm}$ and $1.86 \pm 0.08 \mathrm{~cm}, 2.77 \pm 0.90 \mathrm{~cm}$ and $2.18 \pm 0.07 \mathrm{~cm}, 1.81 \pm 0.034 \mathrm{~cm}$ and $1.4 \pm 0.06$ $\mathrm{cm}, 0.66 \pm 0.014 \mathrm{~cm}$ and $0.56 \pm 0.05 \mathrm{~cm}$ respectively. Finally, total lengths of penis in uncastrated and castrated buck were $30.42 \pm 0.459$ $\mathrm{cm}$ and $28.42 \pm 0.553 \mathrm{~cm}$ respectively. The length and diameter of the neck of the urinary bladder, root, sigmoid flexure, urethral process of the penis are clinically more important for obstructive urolithiasis.
\end{abstract}

KEY WORDS: Black Bengal goat; Gross Anatomy; Urethra; Penis; Urolithiasis.

\section{INTRODUCTION}

Black Bengal goats (BB) are known as poor man's economy in Bangladesh, because of occupying significant position in the predominantly agro based economy of the country. In recent years, goat production ranked second in terms of the total amount of meat and skin production, they have also proved their worth to stand effectively in overall livestock production of the country (Awal et al., 2004). BB goats are very much familiar for their adaptability, prolificacy, delicious meat and skin quality, also recognized as a breed among the domestic species throughout the Bangladesh and they have tremendous demand all over the world due to extra ordinary quality of meat and skin (Fakruzzaman et al., 2012). In different body systems of
BB goat urogenital system is important, where urethra and penis act as a common passage for urine and semen. The urethra has two parts, pelvic urethra and penile urethra. The penis has three parts like root, body and glans penis with or without urethral process .The urethral process and sigmoid flexure are present in buck and ram (Getty et al., 1975). This urogenital tract has both anatomical and clinical importance. Urethral process, distal aspect of the sigmoid flexure, urethra at the pelvic arch and neck of urinary bladder in small ruminants are very much prone to occur obstructive urolithiasis (Gugjoo et al., 2013). Obstructive urolithiasis are commonly occurs in buck than doe, due to longer length and narrower diameter of urethral passage in buck than doe

\footnotetext{
${ }^{1}$ Gentry Pharmaceuticals Ltd, Dhaka, Bangladesh.

2 Dept. of Epidemiology and Public Health; Sylhet Agricultural University, Sylhet, Bangladesh.

${ }^{3}$ Dept. of Genetics and Animal Breeding; Chattogram Veterinary and Animal Sciences University, Khulshi, Chattogram-4225, Bangladesh.

${ }^{4}$ Dept. of Anatomy and Histology; Chattogram Veterinary and Animal Sciences University, Khulshi, Chattogram-4225, Bangladesh.
} 
(Getty et al.; Van Metre \& Smith, 1995). Obstructive urolithiasis in the urethral passage is a difficult problem; long term success requires in surgical management to relive urethral obstruction in small ruminants (Fortier et al., 2004; Van Metre \& Fubini, 2006). For that surgical management, different knowledge like normal anatomy of penis and urethra is important. Presence of castration and age of Castration plays a vital role for the development of urethral passage and occurrence of urolithiasis (Ghoshal \& Bal, 1976). Although several works has been reported on the morphology of urogenital tract of the male goat on different breed (Getty et al.; König et al., 2004; Dyce et al., 2010) but there is no such type of work on BB goat. Therefore, the present study was carried out to establish baseline work on the normal measurement of the urethral passage and different segments of penis of uncastrated and castrated BB goat which will be supportive for obstructive urolithiasis management.

\section{MATERIAL AND METHOD}

This study was conducted on the urogenital tract of $50 \mathrm{BB}$ bucks (25 uncastrated and 25 castrated) at the departments of Anatomy and Histology, faculty of veterinary medicine, Chattogram Veterinary and Animal Sciences University (CVASU), Chattogram, Bangladesh. The goats were adults, apparently healthy and devoid of any external abnormalities and almost same age and weight. The urinary passage (urinary bladder to external urethral orifice) and penis of buck with associated organs were collected from Chattogram City Corporation area. The urogenital tracts were collected scientifically just after skinning of the slaughtered goat without damaging any parts of it. After that, the male urethra and different segments of penis were measured by using metric rules. Mean and variation of the length and diameter of male urethra and different segments of penis (root, body, sigmoid flexure, glans penis and urethral process) in uncastrated and castrated bucks were calculated by using SPSS 11.5 software and necessary photographs were taken for better illustration of methods and result (Fig. 1 to 5).

\section{RESULTS}

Table I showed that, the mean length of the pelvic urethra was $5.88 \pm 0.111 \mathrm{~cm}$ and $4.58 \pm 0.15 \mathrm{~cm}$ in uncastrated and castrated buck respectively. The length and diameter of neck of Urinary Bladder (UB) (Fig. 1)

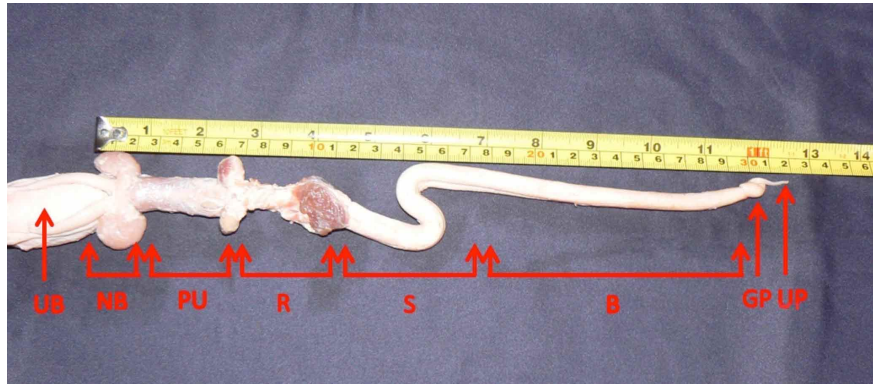

Fig. 1. Different portion of urethra and penis.

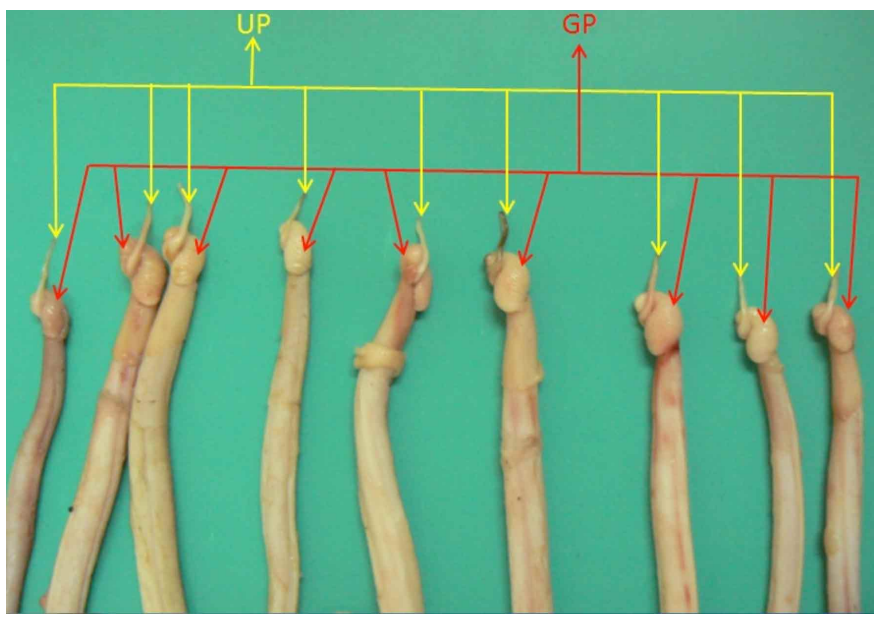

Fig. 2. Size and location of Urethral Process (UP) and Glans Penis (GP).

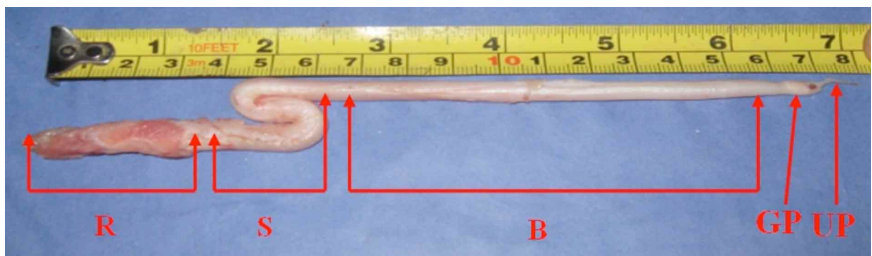

Fig. 3. Root (R), Sigmoid Flexure (S), Body (B), Glans Penis (GP), Urethral Process (UP) of a buck penis.

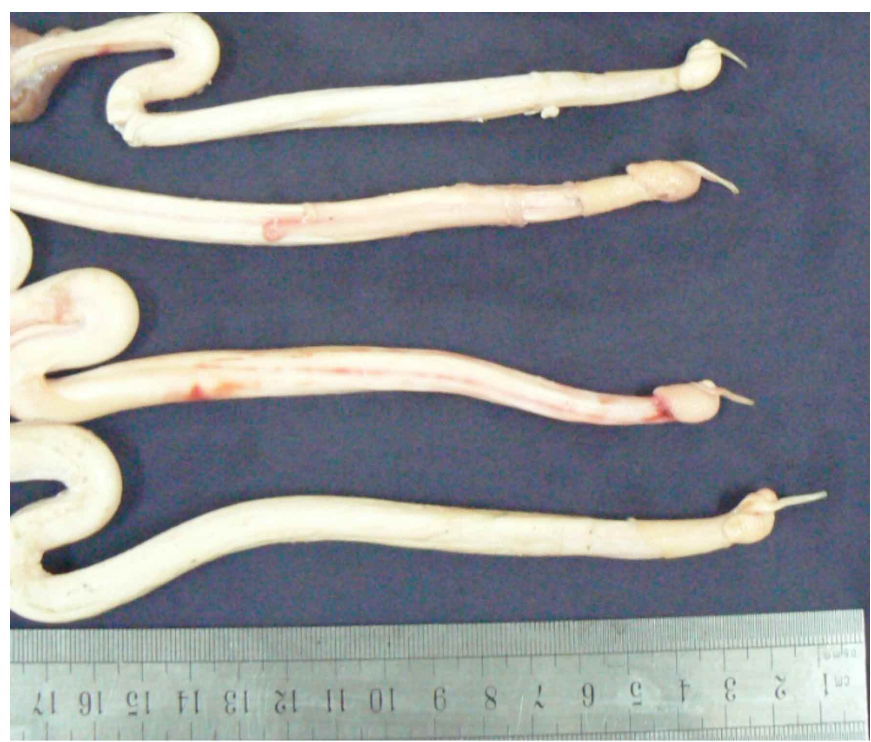

Fig. 4. Series of uncastrated and castrated buck penis. 


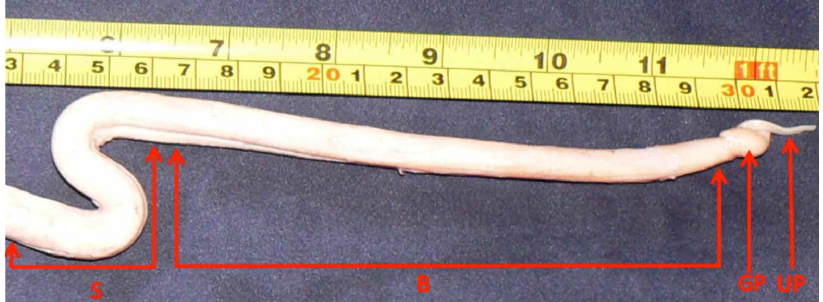

Fig. 5. Different portion of urethra and penis a close view.

in uncastrated and castrated buck was $0.688 \pm 0.156 \mathrm{~cm}$, $0.38 \pm 0.048 \mathrm{~cm}$ and $1.94 \pm 0.041 \mathrm{~cm}, 1.44 \pm 0.05 \mathrm{~cm}$ respectively. The length and diameter of the Root $(\mathrm{R})$ of the penis (Fig. 1) in uncastrated and castrated buck was $5.02 \pm$ $0.09 \mathrm{~cm}, 4.24 \pm 0.10 \mathrm{~cm}$ and $3.7 \pm 0.049 \mathrm{~cm}, 3.3 \pm 0.144 \mathrm{~cm}$ respectively. Similarly, the length and diameter of Body (B) of the penis (Fig. 3) in uncastrated and castrated buck was $23.48 \pm 0.37 \mathrm{~cm}, 22.74 \pm 0.43 \mathrm{~cm}$ and $2.63 \pm 0.066 \mathrm{~cm}, 1.86$ $\pm 0.08 \mathrm{~cm}$ respectively. The length and diameter of Sigmoid Flexure (SF) (Figs. 1, 3 and 5) of penis in uncastrated and castrated buck was $9.2 \pm 0.107 \mathrm{~cm}, 8.18 \pm 0.29 \mathrm{~cm}$ and 2.77 $\pm 0.90 \mathrm{~cm}, 2.18 \pm 0.07 \mathrm{~cm}$ respectively. The length and diameter of the Glans Penis (GP) (Fig. 2) in uncastrated and castrated buck was $1.92 \pm 0.032 \mathrm{~cm}, 1.44 \pm 0.10 \mathrm{~cm}$ and $1.81 \pm 0.034 \mathrm{~cm}, 1.4 \pm 0.06 \mathrm{~cm}$ respectively. The length and diameter of the Urethral Process (UP) (Figs. 1 to 5) were $2.32 \pm 0.029 \mathrm{~cm}, 1.78 \pm 0.07 \mathrm{~cm}$ and $0.66 \pm 0.014 \mathrm{~cm}, 0.56$ $\pm 0.05 \mathrm{~cm}$ in uncastrated and castrated buck respectively. Finally, the total length of penis in uncastrated and castrated buck was $30.42 \pm 0.459 \mathrm{~cm}$ and $28.42 \pm 0.553 \mathrm{~cm}$ respectively (Table I).

List of abbreviations. BB-Black Bengal, B-Body, cmCentimeter, GP-Glans Penis, NB-Neck of Bladder, PUPelvic Urethra, R-Root, S-Sigmoid Flexure, UB-Urinary Bladder, UP-Urethral Process.

Table I. Length and diameter of the pelvic urethra and different segment of the penis in black Bengal goat (in $\mathrm{cm}$ unit). $\mathrm{n}=50$, mean $\pm \mathrm{sd}$

\begin{tabular}{|c|c|c|c|c|c|c|c|}
\hline \multirow{2}{*}{\multicolumn{2}{|c|}{ Parameter }} & \multicolumn{2}{|c|}{ Length } & \multirow{2}{*}{$\begin{array}{l}\text { Diameter } \\
\text { Uncastrated }\end{array}$} & \multicolumn{3}{|c|}{$P$ value } \\
\hline & & Uncastrated & Castrated & & Castrated & Length & Diameter \\
\hline \multicolumn{2}{|c|}{ Pelvic urethra } & $5.88 \pm 0.111$ & $4.58 \pm 0.15$ & - & - & .000 & .000 \\
\hline \multicolumn{2}{|c|}{ Neck of the bladder } & $0.688 \pm 0.156$ & $0.38 \pm 0.048$ & $1.94 \pm 0.041$ & $1.44 \pm 0.05$ & .000 & .000 \\
\hline \multirow{5}{*}{ Penis } & Root & $5.02 \pm 0.09$ & $4.24 \pm 0.10$ & $3.06 \pm 0.049$ & $3.3 \pm 0.144$ & .000 & .000 \\
\hline & Body & $23.48 \pm 0.37$ & $22.74 \pm 0.43$ & $2.63 \pm 0.066$ & $1.86 \pm 0.08$ & .055 & .000 \\
\hline & Sigmoid flexure & $9.2 \pm 0.107$ & $8.18 \pm 0.29$ & $2.77 \pm 0.90$ & $2.18 \pm 0.07$ & .000 & .000 \\
\hline & Glans penis & $1.92 \pm 0.032$ & $1.44 \pm 0.10$ & $1.81 \pm 0.034$ & $1.4 \pm 0.06$ & .000 & .000 \\
\hline & Urethral process & $2.32 \pm 0.029$ & $1.78 \pm 0.07$ & $0.66 \pm 0.014$ & $0.56 \pm 0.05$ & .000 & .000 \\
\hline \multicolumn{2}{|c|}{ Total length } & $30.42 \pm 0.459$ & $28.42 \pm 0.553$ & - & - & .000 & .000 \\
\hline
\end{tabular}

\section{DISCUSSION}

The mean length of the Pelvic Urethra (PU) (Table I) in uncastrated buck was significantly $(\mathrm{p}<0.001)$ higher than the castrated buck, where pelvic urethra is about 5 to $12 \mathrm{~cm}$ in bull and is 15 to $20 \mathrm{~cm}$ in boar (Getty et al.). The length and diameter of neck of urinary bladder in uncastrated buck was significantly $(\mathrm{p}<0.001)$ higher than the castrated buck. The length and diameter of neck of urinary bladder is variable from species to species and which can be a place for storage of calculi. The length and diameter of the root of the penis in castrated buck was significantly $(p<0.001)$ lower than the uncastrated buck. Due to smaller diameter there is a chance of obstruction due to calculi formation in castrated buck. The length and diameter of the body of penis in uncastrated buck was significantly $(\mathrm{p}<0.001)$ higher than the castrated buck. Similarly, the mean value for the length and diameter of the Sigmoid flexure of penis in uncastrated buck was significantly higher $(\mathrm{p}<0.001)$ than the castrated buck. In bull, there is an $\mathrm{S}$ shape curved sigmoid flexure in the penis which is just caudal to the scrotum; which is about $30 \mathrm{~cm}$ of the penis folded up when it is fully retracted. In case of boar the sigmoid flexure is prescrotal, where absent in dog, cat and horse (Getty et al.; Ghosh, 2006) that indicate the sigmoid flexure of penis is common for buck, bull and boar. This sigmoid flexure has surgical importance because the $\mathrm{S}$ shaped sigmoid flexure is quite prone to calculi obstruction which is located just behind the testicle (Kinsley et al., 2013). This flexure frustrates all attempts at passing a catheter from the penis to the bladder because of its curvature (Ewoldt et al., 2006). The mean length and diameter of the glans penis in castrated buck was significantly $(\mathrm{p}<.001)$ lower than the uncastrated buck. Glans penis is $8 \mathrm{~cm}$ in Bull (Getty et al.) which is higher than buck; it may due to species and size variation. The glans penis is very different forms and minimally develops in pigs, substantial in the ruminants but large and mushroom shaped in horse. In case of dog proximal part of glans penis is bulbar and distal part 
cylindrical but in cat it is pointing caudoventrally (Dyce et al.). In case of length and diameter of urethral process of uncastrated buck was significantly $(\mathrm{p}<0.001)$ higher than the castrated buck. In buck at the terminal part of the penis it was found urethra lies in a groove on the ventral surface of corpus cavernosum. The terminal part was projected about $3-4 \mathrm{~cm}$ and 2 to $3 \mathrm{~cm}$ beyond the glans penis forming a twisted process of urethra; the description was found similarity with some previous description (Getty et al.; König et al.). In buck urethral process of the penis is common site for obstructive urolithiasis (Kinsley et al.; Tobias \& van Amstel, 2013). Young castrated males are susceptible to urinary calculi because castration stopped both testosterone production and growth of urethra (Ghoshal \& Bal; Pugh \& Baird, 2012). The tendency of the occurring urolithiasis also related to the anatomy of urinary tract and age of castration (Gugjoo et al.; Cruze, 2014). The total length of penis is also significantly lower $(\mathrm{p}<0.001)$ in castrated buck than the uncastrated one. Generally, in horse the total length of penis is about $50 \mathrm{~cm}$ in quiescent state, whereas the length of penis is about $90 \mathrm{~cm}$ in bull, 45 to $50 \mathrm{~cm}$ in boar and $10 \mathrm{~cm}$ in dog (Getty et al.), which indicate length of buck penis was smaller than bull, horse and boar, it might be due to body size and species variation. From the above discussion it can be said that, castration reduce the growth and development of male urethra and penis (Table I) which could be a cause of urolithiasis formation, those thought found the similarity with some of the previous study (Ghoshal \& Bal).Therefore it can say that, the mean length and diameter of the penile urethra and different segment of the penis in uncastrated buck was significantly $(\mathrm{p}<0.001)$ higher than the castrated buck, which indicate there is more chance of occurring urolithiasis in castrated buck than uncastrated one due to underdeveloped urethra and penis in BB goat.

\section{ACKNOWLEDGMENTS}

The authors acknowledge to University Grants Commission of Bangladesh for funding, Butcher for helping in collection of sample and all members of Department of Anatomy and Histology of Chattogram Veterinary and Animal Sciences University for full time support.

ISLAM, R.; AHMED, S. S. U.; FARUK, M. O.; KIBRIA, A. S. M. G.; FARUQ, A. A. \& UDDIN, M. M. Anatomía macroscópica de la uretra y el pene en macho castrado y no castrado de cabra de Bengala negra. Int. J. Morphol., 39(1):138-142, 2021.

RESUMEN: El proceso uretral, el ángulo sigmoideo, la uretra en el arco pélvico y el cuello de la vejiga urinaria en las cabras son muy propensos a formar urolitiasis obstructiva. El pre- sente estudio se llevó a cabo para establecer un trabajo de referencia sobre la medición normal del pasaje uretral y diferentes segmentos de pene de cabra de Bengala Negra (BB) no castrada y castrada, que serán de apoyo para el manejo de la urolitiasis obstructiva. Se recolectaron diferentes segmentos de pene junto con la uretra de 25 machos de cabras de Bengala negras sin castrar y 25 castrados de diferentes mataderos de Chattogram City Corporation. La longitud y el diámetro de la uretra y los diferentes segmentos del pene en el macho no castrado fueron significativamente más altos $(\mathrm{p}<0,001)$ que en el macho castrado. La longitud de la uretra pélvica fue de $5,88 \pm 0,111 \mathrm{~cm}$ y $4,58 \pm$ $0,15 \mathrm{~cm}$ en animales sin castrar y castrados, respectivamente. La longitud del cuello de la vejiga urinaria; raíz, cuerpo, flexión sigmoidea, glande del pene y proceso uretral del pene en el macho sin castrar y castrado fueron $0,688 \pm 0,156 \mathrm{~cm}$ y $0,38 \pm 0,048 \mathrm{~cm}$, $5,02 \pm 0,09 \mathrm{~cm}$ y $4,24 \pm 0,10 \mathrm{~cm}, 23,48 \pm 0,37 \mathrm{~cm}$ y $22,74 \pm 0,43$ $\mathrm{cm}, 9,2 \pm 0,107 \mathrm{~cm}$ y $8,18 \pm 0,29 \mathrm{~cm}, 1,92 \pm 0,032 \mathrm{~cm}$ y $1,44 \pm$ $0,10 \mathrm{~cm}, 2,32 \pm 0,029 \mathrm{~cm}$ y $1,78 \pm 0,07 \mathrm{~cm}$, respectivamente. El diámetro del cuello de la vejiga urinaria, la raíz, el cuerpo, el ángulo sigmoide, el glande del pene y el proceso uretral del pene en el macho no castrado y castrado fueron $1,94 \pm 0,041 \mathrm{~cm}$ y $1,44 \pm$ $0,05 \mathrm{~cm}, 3,7 \pm 0,049 \mathrm{~cm}$ y $3,3 \pm 0,144 \mathrm{~cm} .2,63 \pm 0,066 \mathrm{~cm}$ y 1,86 $\pm 0,08 \mathrm{~cm}, 2,77 \pm 0,90 \mathrm{~cm}$ y $2,18 \pm 0,07 \mathrm{~cm}, 1,81 \pm 0,034 \mathrm{~cm}$ y 1,4 $\pm 0,06 \mathrm{~cm}, 0,66 \pm 0,014 \mathrm{~cm}$ y $0,56 \pm 0,05 \mathrm{~cm}$ respectivamente. Finalmente, las longitudes totales de pene en machos castrados y no castrados fueron de $30,42 \pm 0,459 \mathrm{~cm}$ y $28,42 \pm 0,553 \mathrm{~cm}$ respectivamente. La longitud y el diámetro del cuello de la vejiga urinaria, la raíz, el ángulo sigmoideo y el proceso uretral del pene son clínicamente más importantes para la urolitiasis obstructiva.

PALABRAS CLAVE: Cabra de Bengala negra; Anatomía macroscópica; Uretra; Pene; Urolitiasis.

\section{REFERENCES}

Awal, M. A.; Rahman, M. M.; Das, S. K.; Siddiki, N. H.; Kurohmaru, M.; Bibin, A. B. \& Hayashi, Y. Formalin affects the male reproduction of black bengal goats during prepubertal stage even at low concentration: in vivo study. J. Med. Sci., 4(1):84-9, 2004.

Cruze, C. Urolithiasis in Goats. Tennesse, 2nd Annual Veterinary Partners Appreciation Conference, University of Tennessee College of Veterinary Medicine, 2014.

Dyce, K. M.; Sack, W. O. \& Wensing, C. J. G. Textbook of Veterinary Anatomy. $4^{\text {th }}$ ed. St. Louis, Saunders/Elsevier, 2010. pp.193-5.

Ewoldt, J. M.; Anderson, D. E.; Miesner, M. D. \& Saville, W. J. Shortand long-term outcome and factors predicting survival after surgical tube cystostomy for treatment of obstructive urolithiasis in small ruminants. Vet. Surg., 35(5):417-22, 2006.

Fakruzzaman, M.; Akter, Q. S.; Husain, S. S.; Khandoker, M. A. M. Y.; Apu, A. S. \& Islam, M. R. Estrus characteristics of black bengal does under intensive condition. Iran. J. Appl. Anim. Sci., 2(1):89-95, 2012.

Fortier, L. A.; Gregg, A. J.; Erb, H. N. \& Fubini, S. L. Caprine obstructive urolithiasis: requirement for 2 nd surgical intervention and mortality after percutaneous tube cystostomy, surgical tube cystostomy, or urinary bladder marsupialization. Vet. Surg., 33(6):661-7, 2004.

Getty, R.; Sisson, S. \& Grossman, J. Sisson and Grossman's the Anatomy of the Domestic Animals. $5^{\text {th }}$ ed. Philadelphia, Saunders, 1975. pp.93946 . 
Ghosh, R. K. Primary Veterinary Anatomy. $6^{\text {th }}$ ed. Kolkata, Current Books International, 2006. pp.236-45.

Ghoshal, N. G. \& Bal, H. S. Histomorphology of the urethral process of the goat (Capra hircus). Acta Anat. (Basel), 94(4):567-73, 1976.

Gugjoo, M. B.; Zama, M.; Mohsina, A.; Saxena, A. \& Sarode, I. Obstructive urolithiasis in buffalo calves and goats: incidence and management. $J$. Adv. Vet. Res., 3(3):109-13, 2013.

Kinsley, M. A.; Semevolos, S.; Parker, J. E.; Duesterdieck-Zellmer, K. D. \& Huber, M. Use of plain radiography in the diagnosis, surgical management, and postoperative treatment of obstructive urolithiasis in 25 goats and 2 sheep. Vet. Surg., 42(6):663-8, 2013.

König, H. E.; Liebich, H. G. \& Bragulla, H. Veterinary Anatomy of Domestic Mammals: Textbook and Colour Atlas. $4^{\text {th }}$ ed. Stuttgart, Schattauer, 2004. pp.407-22.

Pugh, D. G. \& Baird, N. N. Sheep and Goat Medicine. $2^{\text {nd }}$ ed. Maryland Heights, Elsevier/Saunders, 2012. pp.255-76.

Tobias, K. M. \& van Amstel, S. R. Modified proximal perineal urethrostomy technique for treatment of urethral stricture in goats. Vet. Surg., 42(4):455-62, 2013.

Van Metre, D. C. \& Fubini, S.L. Ovine and caprine urolithiasis: another piece of the puzzle. Vet. Surg., 35(5):413-6, 2006.

Van Metre, D. C. \& Smith, B. Surgical Treatment of Urolithiasis in Food Animals. Proc. Adv. Vet. Clin. Med., 4(1):13-7, 1995.
Corresponding author:

Abdullah Al Faruq

Assistant Professor

Dept. of Anatomy and Histology

Chattogram Veterinary and Animal SciencesUniversity

Khulshi

Chattogram-4225

BANGLADESH

Email: faruqabdullahal103@gmail.com

Received: 03-08-2020

Accepted: $20-10-2020$ 